\title{
Technological Co-Operation and Contribution among OIC Members with Special Reference to Bangladesh and Iraq
}

\author{
Nayeem Md. Lutful Huq \\ Abdi O. Shuriye \\ Faculty of Engineering, International Islamic University Malaysia \\ Gombak, KL, Malaysia \\ Corresponding Author: shuriye@hotmail.com
}

\section{Doi:10.5901/jesr.2013.v4n3p401}

\section{Abstract}

Science and technology is a pair of the most prominent words to day. To understand the natural systems is Science and technology is the way to control or to implement it for ourselves. Scientists set a goal to attain something, which ordinary people could hardly imagine, and then work to reach there in a very rational and methodical approach. Thus in combination of science and technology we get upgraded systems for the welfare of humanity. In present days, technology is the key indicator for development. While cooperation or collaboration, among the societies, is an essential mean for development. Scientific and technical journal articles are one of the most important science and technology indicators. This paper discusses to major aspects of development; cooperation and contribution. Firstly, the present condition of science and technology and the cooperation in these fields among the members of IOC is discussed here. Where it is found that the most of the members are lagging behind the developed world and more alarming problem is there is a very little cooperative effort among the OIC members themselves. Due to not having adequate knowledge, technology, and support sometimes, they are bound to collaborate more with non-OIC countries than the members do. In spite of that, there is still a huge opportunity to overcome these problems as the OIC members have been blessed by the natural resources and thus have the financial support to overcome any obstacle. To do so, the members need to be more cooperative to each other in all sectors of research and development. They need to remain united as a single body to uphold the brotherhood. Secondly, good contribution to the field of science and technology indicates the smart society of the present time. The advancement in these sectors is an indication of living standard of the people. Here, the roles of two countries, Bangladesh and Iraq, in the field of science and technology, have been discussed. Both the countries have a long history, in different names under different era of kingship. Bangladesh has a large population, near about 146.6 million, of which almost 89\% is Muslim (BBS, 2011), so as a member of OIC she holds of great importance in South Asia. It is remarked that the ancient Bengal was neither developed nor focused as a future technological base by any of the rulers. However, in last two decades she is been showing a consistently rising pattern in these fields especially in agriculture and IT sectors. However, Bangladesh is still far away to have a standard infrastructure for R\&D in science and technology. On the other hand, the land of Iraq has been the mother of world's first civilization and as a Muslim country; Iraq has a glorious history of about thousand years in almost all sectors of development. Nevertheless, in the last few decades, the consecutive involvement in war, killed hundreds of scientist, and destroyed many research facilities, institutions, universities, which eventually destroyed the knowledge base and led Iraq almost to a blind alley. Now it is inevitable for her to reconcile and fight back.

Keywords: OIC, Technology, Science, Iraq, Bangladesh, Innovation

\section{Introduction}

"United-you stand; Divided-you fall" with this value the Organization of Islamic Cooperation (OIC) was formed. Formerly it was named as Organization of the Islamic Conference. OIC is the second largest inter-governmental organization after the United Nations. It has 57 members, spread over four continents. The Organization is the commune body of the Muslim world that make sure to preserve and watch over the welfare of the Muslim world in the spirit of upholding global serenity and synchronization among various people of the world. The Organization was established upon a decision of the historical summit, which took place in Rabat, Kingdom of Morocco on 25 September 1969 (OIC, 2011) which was a result of criminal arson of Al-Aqsa Mosque in occupied Jerusalem.

The fifty-seven states of the OIC are located in different subcontinents. They have different geography, climate, environment, culture, and natural resources. The political, economic, and social histories of the countries are also 
different. One fourth of the world population is in OIC countries (OIC, 2011). The 70 percent of the total energy of the world is under these countries and 40 percent of other mineral resources belong to them as well. Nevertheless, despite of having all these wealth 40 percent of the member countries are low-income developing countries according to UNCTAD (Dabour, 2000).

In today's world technology is the one of the main indication development and knowledge of a society or a country because starting from the drinking water and food to the health care, infrastructure, environmental protection and sustainable development, demand a significant scientific capability. Rand Corporation (Wagner, 2001) has developed a composite index for measuring a country's technological capacity covering input and output indicators. Countries are classified in four groups: scientifically advanced, scientifically proficient, scientifically developing and scientifically lagging countries. The third category, called scientifically developing 24 countries operate at lower scientific capability than international average. These countries have invested substantial amount in science and technology but their scientific capacity is below international average. Nine OIC countries are placed in this group are; Turkey, Egypt, Iran, Malaysia, Pakistan, Tunisia, Nigeria, Uganda, Uzbekistan. The rest 49 OIC countries are grouped among 80 scientifically lagging countries. UNDP Technological Achievement Index (TAl) (Desai, 2002) classifies countries as leaders, potential leaders, dynamic adopters and marginalized countries. Not a single OIC member state is ranked among 18 countries termed as technology leaders. Just one country Malaysia is included in a group of 19 countries classified as potential leaders. Iran, Egypt, Indonesia, Tunisia, Algiers, Egypt are grouped among countries known as dynamic adopters. The rest of OIC countries are classified as either Marginalized or others for which complete data was not available. Availability of reliable data is a severe constraint for measuring scientific capability of OIC countries.

Furthermore, the higher income oil exporting countries are also lagging behind in scientific and technological development due to their indifference and neglect of this sector for decades. Their underinvestment in building human capital and institutions for scientific research has relegated them to a state of perpetual dependence on the developed countries for most of their technological needs. While international technology transfer is important for economic development. Sustained social and economic development cannot be achieved without creating absorptive capacity. Misconceived priorities and the traditional supply focused S\&T policy approach has not resulted in building system or institutions, which transfer technical knowledge to economic advantage. Consequently, the investment that these countries have made to train their brightest is lost to developed countries.

In addition to the above intra OIC cooperative relation, the technological contribution from them is also of high importance. Contribution to the field of science and technology is an indication to the future sustainability of that nation. Bangladesh is a South Asian and Iraq is an Arab country and the members of IOC. Iraq had a good start in its ancient time. She gave birth to most of the ancient civilizations. Again, the incubation of most of the basic scientific effort was done in the same land. Starting from the numerals, calculation of minute, hour, day, week to the year 365 days, to geometry, chemistry, physics, astronomy, medicine and most of the basic science was brought up there. Whereas, Bengal was focused to the cultural and religious aspects for most of its ancient time. Both the nation came in contact with Islam and after that they became as Muslim countries. Iraq is important in OIC because of its history, geographical position, and natural resources among Arab countries and Bangladesh has become significant due to its Muslim population as it has become the third largest country, with respect to population, among the OIC members. OIC combines the Muslim countries in a single string of brotherhood as part of Islamic ideology of one nation. Thus, contribution of one of the members means the achievement for all.

This study discusses about the intra OIC technological cooperation along with its trend, as it is one of the most effective means of development, and the contributions in science and Technology by Bangladesh and Iraq have been highlighted. The OIC was formed with the view of creating a Muslim brotherhood through cooperation, collaboration, assistance, and even working together shoulder to shoulder. To achieve this goal technology, work, and knowledge transfer within the members is inevitable. Thus, this paper has framed a picture of this relationship to with an intension of suggesting steps in fortifying the bond among the countries, which can uphold the brotherhood among them.

\section{Part A - Cooperation among OIC members}

\subsection{Present Technological Condition of IOC Countries}

The available statistics for R\&D expenditure and R\&D work force for most OIC countries is sketchy. It is estimated that OIC countries spend less than 0.42 of their GDP on research and development. This compares poorly with the developed countries average of 2.8-3.5 percent of much higher GDPs. Some oil rich countries such as Saudi Arabia, 
Qatar, Oman, and UAE have invested in attracting excellent universities to establish their subsidiary campuses in their countries. Dubai announced the creation of a US\$10 billion foundation to establish research centers in Arab universities and offer research grants to Arab scientists. Qatar Education city has attracted campuses of seven of the world's top universities. Saudi Arabia has laid foundation for a new university city worth US\$2.6 billion devoted to science and technology. Turkey, Pakistan, Egypt, Malaysia, and Mozambique have also increased their R\&D expenditures in the past decade. Private sector R\&D that is linked to innovations and competitiveness has not been documented for most OIC countries. A World Bank study has reported the average private R\&D expenditure of 33 OIC countries as merely $3.0 \%$ of GDP compared to average 87 and 84\%age of GDP for South Korea and Japan. Statistics on researchers per million population for OIC countries average (525) also compares poorly with developed countries average of 3780 researchers per million. The average number of researchers for OIC western Asian region is higher than OIC African region, (131) per million. Relatively higher number of researchers, 1759 per million are reported for Jordon. This number however, does not correspond to increase in number of publications or patent from Jordon.

Table 1: Research and Enrollment Portrayal of OIC Members (Naim, 2009)

\begin{tabular}{|c|c|c|c|}
\hline Country & $\begin{array}{c}\text { Researchers } \\
\text { (per million people) }\end{array}$ & $\begin{array}{c}\text { Expenditure for } \\
\text { Research (\% of GDP) }\end{array}$ & $\begin{array}{l}\text { Tertiary Gross Enrollments ratio } \\
\text { (\% of relevant age group) }\end{array}$ \\
\hline \multicolumn{4}{|l|}{ Western Asia } \\
\hline Azerbaijan & $1203(2006)$ & $0.25(2005)$ & $15.0(2005)$ \\
\hline Bahrain & N/A & N/A & $33.1(2005)$ \\
\hline Iraq & N/A & 0.5 (2004) & $15.0(2005)$ \\
\hline Jordan & 1927 (1990-05) & $0.43(2002)$ & $39.0(2005)$ \\
\hline Kuwait & 242 (1996-05) & $0.2(2006)$ & $18.0(2005)$ \\
\hline Lebanon & N/A & $\mathrm{N} / \mathrm{A}$ & $51.0(2005)$ \\
\hline Oman & $3.43(2006)$ & $\mathrm{N} / \mathrm{A}$ & $15.0(2005)$ \\
\hline Palestine & N/A & N/A & 41.1 (2005) \\
\hline Qatar & $\mathrm{N} / \mathrm{A}$ & $\mathrm{N} / \mathrm{A}$ & $18.6(2005)$ \\
\hline Saudi Arabia & $140(1996-04)$ & $\mathrm{N} / \mathrm{A}$ & $28.0(2005)$ \\
\hline Syria & $29(2006)$ & $0.2(2006)$ & $14.8(1997)$ \\
\hline Turkey & 476 (2006) & $0.79(2006)$ & $31.0(2005)$ \\
\hline UAE & N/A & N/A & $22.0(2005)$ \\
\hline Yemen & $\mathrm{N} / \mathrm{A}$ & $0.28(2005)$ & $9.0(2005)$ \\
\hline \multicolumn{4}{|l|}{ South East Asia } \\
\hline Brunei Darussalam & $274(1990-05)$ & $0.01(2003)$ & 15 (2005) \\
\hline Indonesia & 207 (1990-05) & $0.1(2006)$ & $17(2005)$ \\
\hline Malaysia & 509 (2006) & $0.63(2006)$ & $32(2005)$ \\
\hline \multicolumn{4}{|l|}{ Southern Asia } \\
\hline Afghanistan & N/A & N/A & $1(2005)$ \\
\hline Bangladesh & 77 (1996-04) & $0.62(2000-04)$ & $6(2005)$ \\
\hline Iran & $1279(2006)$ & $0.59(2006)$ & $24(2005)$ \\
\hline Maldives & N/A & N/A & $0.2(2004)$ \\
\hline Pakistan & $350\left(2007^{\star \star}\right)$ & $0.9\left(2007^{\star \star}\right)$ & $5(2005)$ \\
\hline \multicolumn{4}{|l|}{ Central Asia } \\
\hline Kazakhstan & 786 (2006) & $0.28(2006)$ & $53(2005)$ \\
\hline Kyrgyzstan & 397 (2007) & $0.22(2005)$ & $41(2005)$ \\
\hline Tajikistan & N/A & $0.10(2006)$ & $17(2005)$ \\
\hline Turkmenistan & $\mathrm{N} / \mathrm{A}$ & $0.6(2006)$ & $19.5(1997)$ \\
\hline Uzbekistan & 1754 (1990-05) & $0.3(2006)$ & 15 (2005) \\
\hline \multicolumn{4}{|l|}{ Western Africa } \\
\hline Benin & N/A & 0.7 (2006) & $3(2001)$ \\
\hline Burkina Faso & 19 (2006) & $0.20(2006)$ & $2(2005)$ \\
\hline Cote divoire & $\mathrm{N} / \mathrm{A}$ & N/A & 6.5 (1999) \\
\hline Gambia & $\mathrm{N} / \mathrm{A}$ & $\mathrm{N} / \mathrm{A}$ & $1(2005)$ \\
\hline Guinea & 342 (1996-04) & N/A & $3(2001)$ \\
\hline
\end{tabular}




\begin{tabular}{|c|c|c|c|}
\hline Guinea Bissau & N/A & $\mathrm{N} / \mathrm{A}$ & $0.4(2005)$ \\
\hline Mali & N/A & N/A & $3(2005)$ \\
\hline Mauritania & N/A & $\mathrm{N} / \mathrm{A}$ & $3(2005)$ \\
\hline Niger & N/A & N/A & $1(2005)$ \\
\hline Nigeria & 800 (2007) & 1 (2004) & 10 (2005) \\
\hline Senegal & $1.34(2006)$ & $0.11(2005)$ & $5(2005)$ \\
\hline Sierra Leone & $\mathrm{N} / \mathrm{A}$ & $\mathrm{N} / \mathrm{A}$ & $2(2005)$ \\
\hline Togo & $102(1990-05)$ & $\mathrm{N} / \mathrm{A}$ & $3.6(2001)$ \\
\hline \multicolumn{4}{|l|}{ Eastern Africa } \\
\hline Comoros & N/A & $\mathrm{N} / \mathrm{A}$ & $2.3(2004)$ \\
\hline Djibouti & N/A & N/A & $2.2(2005)$ \\
\hline Mozambique & 132 (1996-04) & $0.52(2006)$ & $1(2005)$ \\
\hline Somalia & N/A & $\mathrm{N} / \mathrm{A}$ & 2.5 (1997) \\
\hline Uganda & 37 (1996-04) & $1.25(2006)$ & $3(2005)$ \\
\hline \multicolumn{4}{|l|}{ Northern Africa } \\
\hline Algeria & N/A & 0.19 (2004) & 20 (2005) \\
\hline Egypt & 493 (1990-05) & 0.49 (1995) & 33 (2005) \\
\hline Libya & 361 (1990-05) & N/A & 56 (2005) \\
\hline Morocco & 782 (1996-04) & 0.75 (2006) & 11 (2005) \\
\hline Sudan & 252 (2006) & 0.4 (2006) & $6.2(2000)$ \\
\hline Tunisia & $1460(2006)$ & 1.35 (2006) & 29 (2005) \\
\hline \multicolumn{4}{|l|}{ Middle Africa } \\
\hline Cameroon & 28.31 & $\mathrm{~N} / \mathrm{A}$ & $6(2005)$ \\
\hline Chad & N/A & N/A & $1(2005)$ \\
\hline Gabon & 109 (1996-04) & $\mathrm{N} / \mathrm{A}$ & 7.10 (2005) \\
\hline \multicolumn{4}{|c|}{ South America and European Region } \\
\hline Albania & N/A & $\mathrm{N} / \mathrm{A}$ & $20(2005)$ \\
\hline Guyana & N/A & N/A & $10.8(2005)$ \\
\hline Suriname & N/A & N/A & $12.4(2002)$ \\
\hline
\end{tabular}

\subsection{Picture of Cooperation among OIC Members}

The OIC aims to promote solidarity and cooperation among its member states and to secure their common interests at the international arena. When it was established in 1969, it had started as a political forum. Yet, it was soon realized that for a joint political action to be effective, it had to be based upon and complemented by wide-ranging cooperation activities in various fields. This idea was put forward at the First Islamic Conference of Foreign Ministers (ICFM) held in Jeddah, March 1970. It declared that the participating governments should consult together with a view to promoting close cooperation and mutual assistance in the economic, technical, scientific, cultural, and spiritual fields.

In the ninth session of the Standing Committee for Economic and commercial Co-operation (COMCEC) of OIC, it was thought important to have certain major objectives that would represent a vision of what OIC co-operation should aim at (OIC, 1997). It was in terms of not only intra-community achievements, but also in terms of the place and role of the OIC countries in the global economy. In this context, decision was made for improving the quality of human capital and reducing the technology gap between the OIC community and the developed world by enhancing the level of Research and Development activities. Several programs were taken to improve different sectors. Some of the programs to improve in research and development are as follows;

\subsubsection{Food, Agriculture, and Rural Development}

1. Promoting and expanding co-operation in the area of agricultural research and development of joint activities, by giving a pivotal role to the private sector.

2. Developing modalities of co-operation and joint action among the member countries to enhance food security promote collective self-reliance and ensure continuity of supply in food for the OIC community.

3. Overcoming major threats to food production caused by plant and animal pests and diseases through Early 
Warning Systems and other coordinated mechanisms among interested member countries.

4. Identification and implementation of joint ventures in the area of food and agricultural production, with the active participation of the private sector, that will optimally utilize the existing resources and potentials in the OIC member countries in order to expand output and improve productivity in various sub-sectors.

\subsubsection{Industry}

1. Promoting contacts among industrialists of the member countries to share information and experiences that will help enhance private sector co-operation in this area.

2. Developing appropriate policies and measures in the member states conducive to OIC co-operation in industrial investment, production and trade of industrial products.

3. Exploring ways and means for a fuller and more optimal utilization of the existing natural, human and technological resources, facilities and potentials in the member countries to promote industrial cooperation and development in the Islamic world;

4. Establishment of joint industrial ventures, with special emphasis on private sector co-operation, in order to create linkages between member country economies, expand the supply of indigenously produced manufactures and increase the manufactures export capacity of the member countries.

\subsubsection{Energy and mining}

1. Promoting co-operation among the member countries in order to ensure a more efficient supply, distribution, and utilization of energy and processing of minerals on a sub-regional and regional basis.

2. Securing co-operation and co-ordination between the scientific research and development centers in the member countries, with a view to consolidating and enhancing the overall R\&D capacity in the OIC countries.

\subsubsection{Technology and Technical Co-operation}

1. Developing the national science base and technology development capability in the member countries to affect positive impacts on economic growth and sustainable development.

2. Strengthening of the national institutions operating in the area of technical co-operation and technology with a view to enhancing and building up their capacities and capabilities to facilitate co-operation among member countries.

3. Creation of the conducive environment in the member countries for the promotion and expansion of technical co-operation and technology related activities among them.

4. Designating national focal points, by those member countries that have not yet done so, to act as major reference points in the process of exchanging information and experiences and for the identification of national needs and capacities in the OIC community with respect to technical co-operation and technology-related activities.

5. Promoting, expanding, and developing technical and technological co-operation activities and programs among the member countries.

6. Making best use of the existing OIC mechanisms in the field of technical co-operation and inviting the IDB and other OIC institutions to increase their allocations in this regard.

\subsubsection{Environment}

1. Designing of special programs on environmental issues among the member countries in the areas of education, training, and technical cooperation.

2. Establishing and developing direct contacts and co-operation, at the regional and OIC level, among the scientific and technological communities and decision-makers on the issues related to the environment.

3. Development of co-operative schemes among the member countries for combating emergencies and other developments that threaten to create environmental hazards and cause damage to public health.

4. Integrating environmental considerations into economic development plans, programs and policies, as well as in specific areas of economic activity, at the national level, and in the OIC economic co-operation activities and joint action. 
After setting these plans of actions, OIC also took some means of follow-up and implementation. Thus some changes took place in the relation among the member countries of OIC. At present there are several highly cited research institutes among OIC countries.

Table 2: OIC Research Institutes (Highly Cited) (Naim, 2009)

\begin{tabular}{|c|c|c|}
\hline Sn. & Institute & Country \\
\hline \multicolumn{3}{|c|}{ Eastern Africa } \\
\hline 1. & Makerere University Uganda & Uganda \\
\hline 2. & Virus Research Institute & Uganda \\
\hline \multicolumn{3}{|c|}{ Northern Africa } \\
\hline 1. & Ain Shams University & Egypt \\
\hline 2. & Cairo University & Egypt \\
\hline 3. & Mansoura University & Egypt \\
\hline 4. & University of Alexandria & Egypt \\
\hline \multicolumn{3}{|c|}{ Western Asia } \\
\hline 1. & Kuwait University & Kuwait \\
\hline 2. & American University of Beirut & Lebanon \\
\hline 3. & Sultan Qaboos University & Oman \\
\hline 4. & King Fahd University of Petroleum and Minerals & Saudi Arabia \\
\hline 5. & King Faisal Specialist Hospital \& Research Centre & Saudi Arabia \\
\hline 6. & King Saud University & Saudi Arabia \\
\hline 7. & Akdeniz University & Turkey \\
\hline 8. & Ankara University & Turkey \\
\hline 9. & Ataturk University & Turkey \\
\hline 10. & Başkent University & Turkey \\
\hline 11. & Bilkent University & Turkey \\
\hline 12. & Bogazici University & Turkey \\
\hline 13. & Ege University & Turkey \\
\hline 14. & Gazi University & Turkey \\
\hline 15. & Gaziantep University & Turkey \\
\hline 16. & Hacettepe University & Turkey \\
\hline 17. & Inonu University & Turkey \\
\hline 18. & Istanbul Technical University & Turkey \\
\hline 19. & University of Istanbul & Turkey \\
\hline 20. & Karadeniz Technical University & Turkey \\
\hline 21. & Marmara University & Turkey \\
\hline 22. & Nigde University & Turkey \\
\hline 23. & Uludag University & Turkey \\
\hline 24. & United Arab Emirates University & UAE \\
\hline \multicolumn{3}{|c|}{ South-East Asia } \\
\hline 25. & University of Malaya & Malaysia \\
\hline 26. & University Sains Malaysia & Malaysia \\
\hline \multicolumn{3}{|c|}{ Southern Asia } \\
\hline 1. & Amirkabir University of Technology & Iran \\
\hline 2. & Bu-Ali Sina University & Iran \\
\hline 3. & Iran University of Science \& Technology & Iran \\
\hline 4. & Isfahan University of Technology & Iran \\
\hline 5. & Islamic Azad University & Iran \\
\hline 6. & Razi University & Iran \\
\hline 7. & Sharif University of Technology & Iran \\
\hline 8. & Shiraz University & Iran \\
\hline 9. & Tarbiat Modarres University & Iran \\
\hline 10. & Tehran University of Medical Science & Iran \\
\hline
\end{tabular}




\begin{tabular}{|lll|}
\hline 11. & Tehran University & Iran \\
\hline 12. & Aga Khan University & Pakistan \\
\hline 13. & Quaid-i-Azam University & Pakistan \\
\hline
\end{tabular}

The region of Western Asia has been the most Prolific region in terms of research, which is measured base on the number of research papers published where 14 OIC members hosts. During 1997-2006 scientists of this region have contributed 141520 research articles of which 70\% had been originating from Turkish institutions. After that Saudi Arabia, Jordan, Kuwait and Lebanon provided $23 \%$ and the rest are from the others. But a remarkable factor is Turkey has a very less collaboration with OIC members (less than 10\%). On the other hand Oman has a total collaboration of almost $65 \%$ with the member countries. So the effect of Oman is much enthusiastic for the members than Turkey.

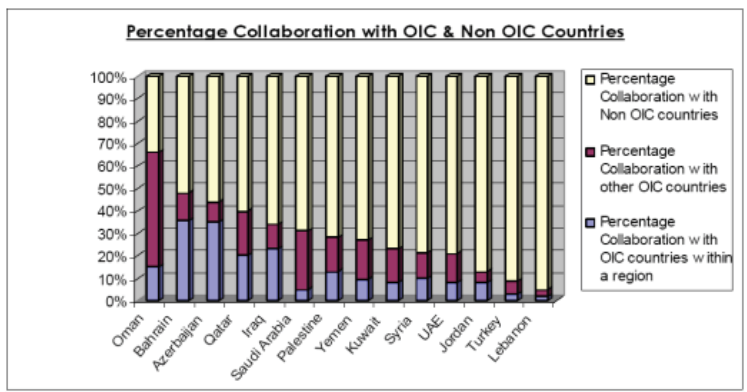

Figure 1: Percentage of Research Article Published in collaboration with.

Southern Asia has five member states of OIC. They contributed, within the same period mentioned earlier, a total of 47,325 research articles. Here Iran has the major contribution among them, $69.6 \%$.

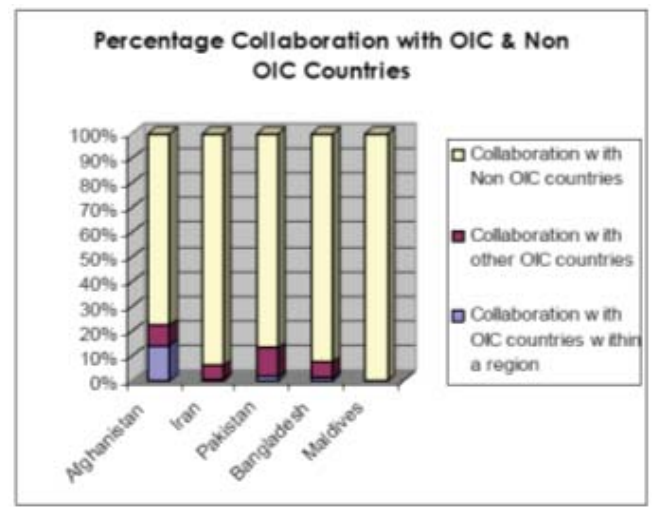

Figure 2: Percentage of Research Article Published in collaboration with.

Again it is found that Afghanistan provided greater option for member countries ( $20 \%$ with members) than Iran (less than $10 \%)$.

There are only three countries in South East Asia who are the members of OIC: Malaysia, Indonesia, and Brunei. But again the picture is similar to the previous regions. Brunei contributed more in collaboration with the member countries that Malaysia, although the variation in this case is not that prominent. 


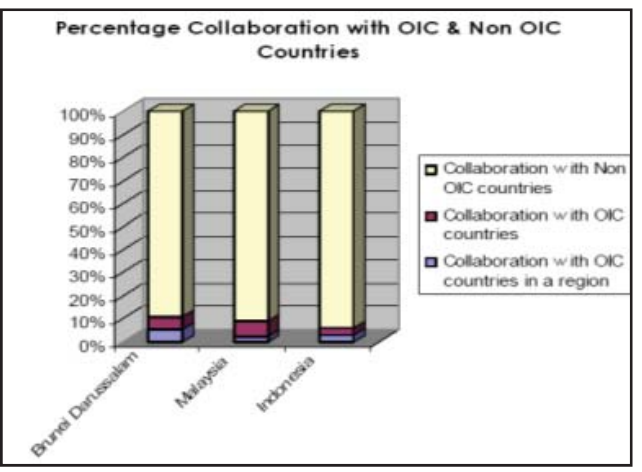

Figure 3: Percentage of Research Article Published in collaboration with.

Central Asia has five OIC member states and published 5966 papers from 1996 to 2007 where $86.6 \%$ paper was originated from Uzbekistan and Kyrgyzstan. Like the observation in general for most OIC countries the Central Asian states have published 83.6\% articles with Russia, Eastern Europe, Western Europe, and USA.

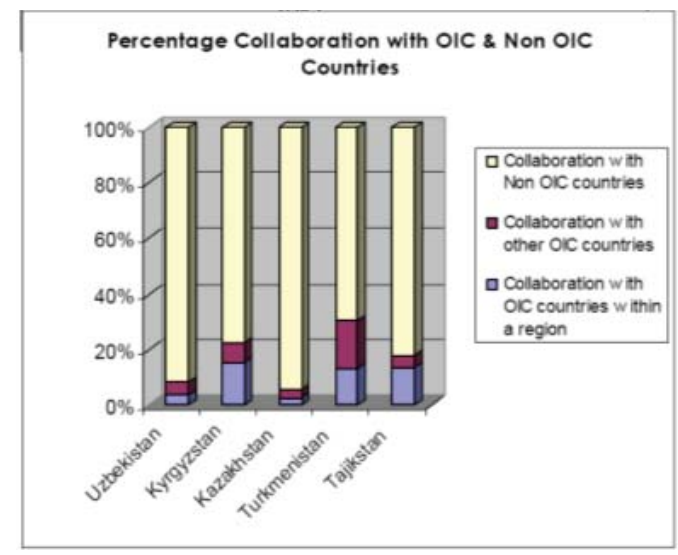

Figure 4: Percentage of Research Article Published in collaboration with.

During the period of 1998-2007, 2704 articles were published and most of those were from Uganda (81\%) in the region Eastern Asia. 


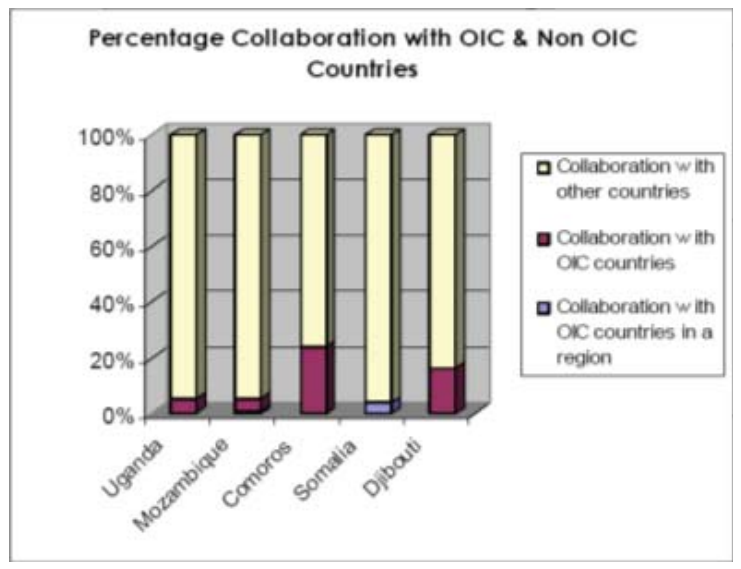

Figure 5: Percentage of Research Article Published in collaboration with.

North Africa, Egypt, Sudan, and Libya contributed almost the similar (near about 20\% each) in collaboration with OIC members. Six countries, which are located in this region, have contributed 53,942 research articles in the ten years period and almost half of those were published by Egypt. Overall $85 \%$ was published in collaboration with the countries in Western Europe and USA.

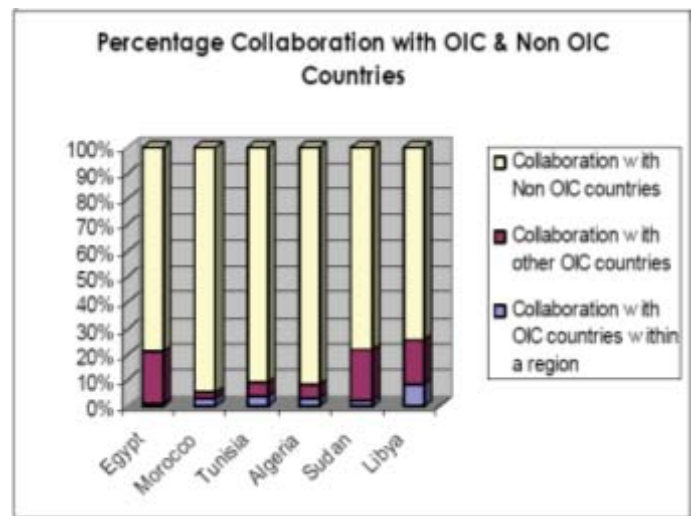

Figure 6: Percentage of Research Article Published in collaboration with.

In West Africa fourteen OIC member states are located. In this region only Burkina Faso, Guinea, Guinea Bissau and Mali have published between 15-20 percent of the total papers published in collaboration within the regional OIC countries among a total of 14518 articles. The average collaboration pattern in this region for all countries is almost $80 \%$ of the articles published with France, USA and other developed countries. 


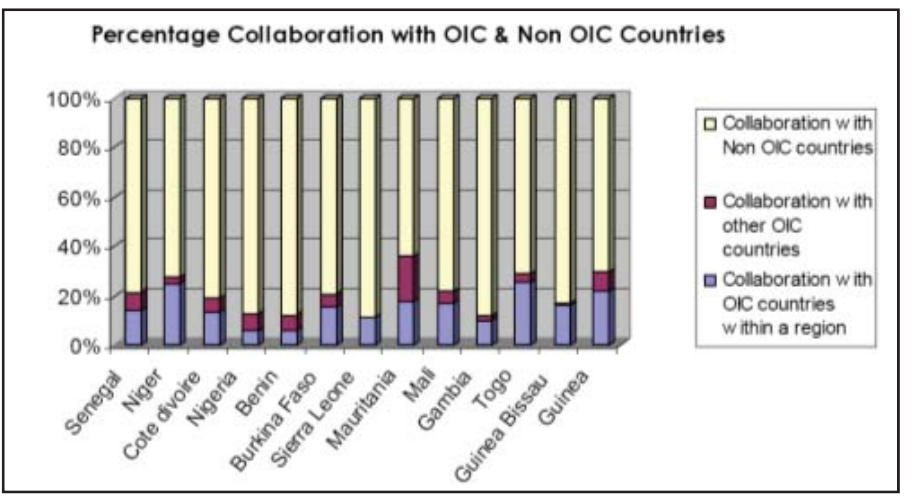

Figure 7: Percentage of Research Article Published in collaboration with.

Chad, Gabon, and Cameroon have contributed 3156 research articles from the Middle African region. Cameroon published $77 \%$ of the total publication of this continent. The overall research collaboration between the regional OIC countries is just $3.3 \%$ of the total papers published in collaboration. These three OIC countries also collaborate preferably with Western Europe and USA (85\%). Collaboration with OIC countries is $11.7 \%$.

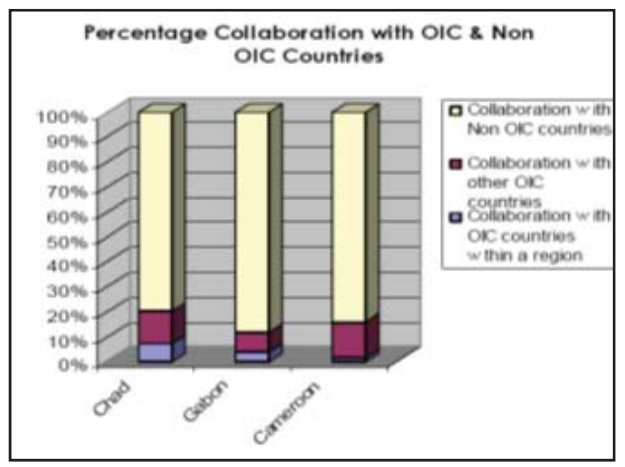

Figure 8: Percentage of Research Article Published in collaboration with.

There are just two OIC Member states located in the South American region: Guyana and Suriname. Guyana contributed 127 research articles and Suriname 37 only during 1998-2007. This region had a very insignificant contribution to OIC member countries or as a whole. On the other hand only one OIC country Albania is in South Europe published 326 research articles during 1997-2006. But $98 \%$ of these were in conjunction with non OIC countries.

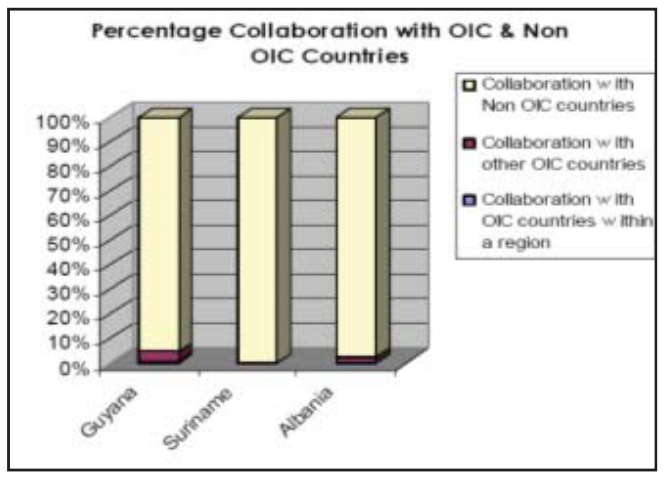

Figure 9: Percentage of Research Article Published in collaboration with. 


\section{Part B - Contributions in Science and Technology (Bangladesh and Iraq)}

\subsection{Short History}

\subsubsection{Bangladesh:}

Figure 10: Bangladesh Political

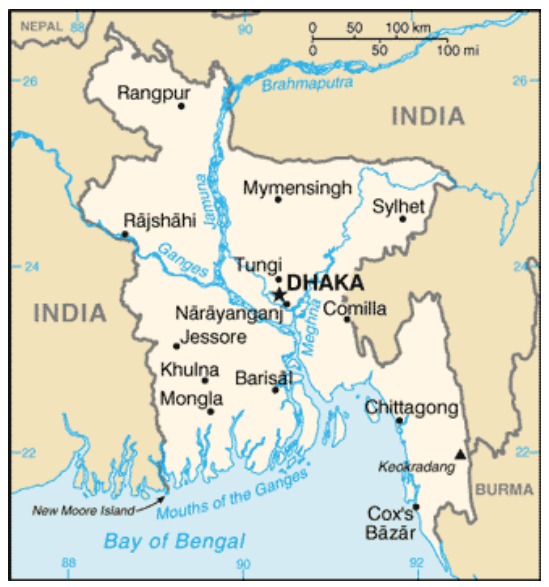

After Alexander carried his victorious arms across the Panjab, and reached the Hyphasis (Bias) River, he was discouraged from advancing further by accounts which reached him of the military strength of two nations by whom his passage of the Ganges would be opposed (Mohan, 2005). The prehistory of Bengal or the origin of the name itself is known a little. The name may be of Austroasiatic or Dravidian origin, which form a substratum to the predominantly IndoEuropean Bengali. In the 3rd century B.C., it was part of the Mauryan Empire and between fourth and sixth century A.D., came under the Guptas. By about 800 A.D., the Pala dynasty ruled Bengal, then known as Vanga (Kulke, 1986). The Sena dynasty, took over from Palas at the turn of 11th century, but were defeated by Qutb-Din-lbaq, the Sultan of Delhi (Sena dynasty, 2013). From the year 1201 to 1757, the Muslim rulers ruled the Bengal. After the death of Aurangjeb (1707), Bengal became independent with the Muslim governors running the administration. Siraj-ud-daula the last independent ruler of Bengal was defeated by the British at the battle of Palassey in June 23, 1757. After seven years of political instability under Mir Jafar, the British annexed Bengal in 1764, in what was to be the first sign of British colonization of India. After a history of 190 years of British colonial command, in 1947 India got its independence in two parts - India and Pakistan (East and West Pakistan).

From West Pakistan to independence, Bangladesh began its journey after her birth through a blood shading war in 1971, at a cost of three million innocent people. Most of them were villagers and commonly they were farmers. The offspring of those people decided to not to leave their four-father's occupation, farming. There was a strong reason behind that, the vast plain and fertile land. Therefore, this was an easy choice for them. There the seed of science and technology was planted in the field of agriculture.

Finally, it was realized that the inherent strength of a nation lies in the skill of its people, which can be enriched through science and technology. The mounting problems of providing for the basic needs of her people and economic development cannot be attained without thinking about science and technology. With this view, a 'National Science and Technology Policy' was adopted in the year 1980, nine years after the liberation. In 1983, govt. constituted "National Committee on Science and Technology" (NTSC) to assist the govt. in the field of science and technology. 


\subsubsection{Iraq:}

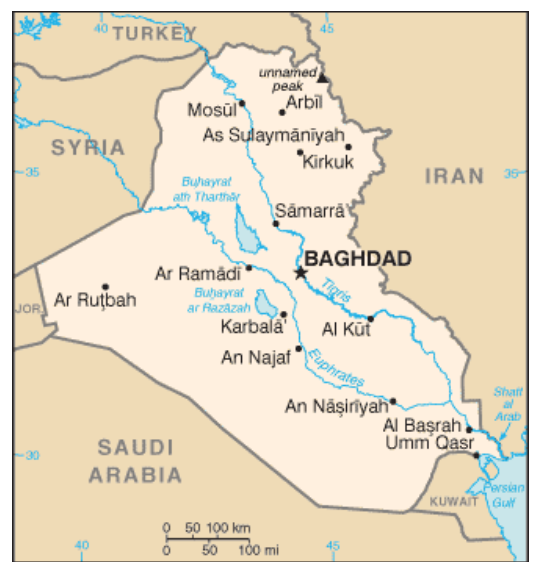

Figure 11: Iraq Political

Thousands of years' history that Iraq has, is full of changing of wind. It is called the "Cradle of Civilization" (Maisels, 1993). The name "Mesopotamia" (Greek word) that stands for "between the rivers" was employed by the Romans for the land between the Euphrates and Tigris, which the eastern most part of Roman Empire (Nissen, 2009). Now it is widely used to denote the territory of Iraq although back then a part of Syria was included in it. About 30 thousand years ago, first human groups, the Neanderthalers, migrated to the place for its climate and natural resources. Between the eighth or seventh millennium several groups' culture are found namely, Ubaid, Halaf, and Samarra.

The first urban society emerged in the southern Mesopotamia in three or four hundred years prior to $3200 \mathrm{BCE}$, the Sumerian city of Uruk and also the writing technique, cuneiform, was developed (Nissen). Sumerians were the most constructive and enticing nation and indeed they began the history. Their contribution in social, economic, and religious sectors put down the bases of ensuing Iraqi civilization (Polok, 2005). It seemed that Uruk was the greatest city on earth for few centuries (Foster, 2009). Day after day with the establishment of colonies, it took a form of state. The artifacts of the Uruk culture travelled a long way from Syria to eastern Iran. By the end of fourth millennium, Uruk's dominance over the area was almost ended up and replaced by local politics. Several evidences show that by the first half of the third millennium, major cities like Kish, Nippur, Isin, Lagash, Eridu, and Ur were of the same category as Uruk. Following 3000 BCE a speedier writing technique and pottery wheel for mass production was developed. The large-scale canal and irrigation systems in the late Uruk period became the trademark of Babylonia. By 2500, BCE Uruk's population reached about 50,000. Therefore, they leached the settlements around it and its 126 neighboring towns shrank to only 24 (Polok). The story of conquest began. Over the centuries the empires rose and fall, these included the Chaldeans, Hittites, Assyrians, Babylonians, the Medes, Greeks (Macedonian and Seleucid), Romans, Parthians, Arabs, Mongols, Ottoman Turks, and the British.

Far away to the southeast from Iraq, a religion was born in the oasis of Mecca and Medina. In seventh century, Islam reached to the land of Iraq. Since then Islam has become essential for Iraqi history that taught them, not to fight with one another and to protect each other. Islam constituted a Muslim community while non-Muslims were to live in peace. It is a long story with lots of ups and downs. However, the goal of this paper is not the history telling so; let us leave that for the historians. Thus, Islam is still the main religion of Iraq and it is a country of Muslim world.

After the fall of the Ottoman Empire $(1300$ - 1922), the British era starts. During the First World War, the British took their steps to protect the oil field in nearby Iran, which they needed for their navy. They immediately introduced the British-Indian laws, police, bureaucracy, and government in their controlled area and treated them as a part of their Indian empire (Polok). British in 1921 constructed Iraq with three provinces namely Basra, Baghdad, and Mosul. They installed a monarchy, a constitution, and parliament and created a modern administrative bureaucracy centered in Baghdad. However, under this government freedom, rights and other forms of mass representation were virtually nonexistence (Haj, 1997). Finally, Iraq got its independence in 1932. 
For the last three decades, Iraq has gone through several wars and it has become a great hammering against its economic, social, diplomatic, political, and technological development. From 1941 until date, Iraq has gone through 11 major wars. There were also some small conflicts within the country. Two major wars, one in 1990-1991 and the other is in 2003-2011, has caused Iraq a major damage to the infrastructure of development. According to the Ministry of education from the year 2003 to 2008 Iraq lost 250 academics, 72 were kidnapped, and 174 were in custody. On the other hand, the Ministry of Human Rights reported that 340 university professors and 446 students were killed between 2005 and 2007 (UN Educational, Scientific, and Cultural Organization 2010). In either case, the loss of brains and youth is huge for a country.

\subsection{Contributions}

\subsubsection{Bangladesh:}

In the field of science and technology, the triumph can be explained as; Bangladesh is ripping as she sown. There are 88 universities - 31 public, 54 privet, and 3 international. Among the public universities there are 11 Technological Universities, 1 Medical University, and some research institute like International Centre for Diarrheal Diseases in Bangladesh (ICDDR'B), National Public Health Institute (NPHI), etc in govt., privet, and international levels.

Table 3: A trend of expenditure in the field of science and technology:

\begin{tabular}{|c|c|c|c|}
\hline Year & $\begin{array}{c}\text { R\&D expenditure as \% } \\
\text { of S\&T expenditure }\end{array}$ & $\begin{array}{c}\text { S\&T expenditure as \% } \\
\text { of GDP }\end{array}$ & $\begin{array}{c}\text { R\&D expenditure as \% } \\
\text { of GDP }\end{array}$ \\
\hline $1994-95$ & 5.93 & 0.24 & 0.01 \\
\hline $1995-96$ & 7.84 & 0.19 & 0.01 \\
\hline $1996-97$ & 7.85 & 0.18 & 0.01 \\
\hline $1997-98$ & 8.54 & 0.24 & 0.02 \\
\hline $1998-99$ & 8.54 & 0.24 & 0.02 \\
\hline $2004-05$ & 9.00 & 0.30 & 0.027 \\
\hline
\end{tabular}

*Estimated using the R\&D grants by University Grants Commission as the basis.

\section{Source: BANSDOC}

From the above data, it is clear that the total amount of budget on R\&D and S\&T has been increasing each year. However, with respect to the GDP the amount is very negligible. Moreover, the increment as a percentage of GDP in S\&T is $0.06 \%$ and in R\&D is $0.017 \%$ in ten years.

\subsubsection{Technology}

The first name that comes here is Fazlur Rahman Khan, a legend of structural engineering and architecture (Ali Mir, 2001). He was the designer of Wills Tower - the tallest building in USA, John Hancock Center etc. He is called the father of tubular design (Richard, 2005). He is regarded as the "Einstein of structural engineering" and the "Greatest Structural Engineer of 20th Century" (Ali Mir, 2001).

Drinking water is a great problem in Bangladesh mostly due to arsenic. Dr. Abul Hussam an entrepreneur developed a "Water Filter to Fight the Arsenic Menace" (Hussam, 2007). Bangladeshi scientist has devised a simple, inexpensive but ingenious technology to treat surface water for drinking that offers a cost-effective substitute to the arsenic-contaminated water, widespread in the country, year 2008 (Gupta, 2008).

Farmers like farming. The most advancement took place in the agro-based research. There are 7 agricultural universities and some agricultural research institute, most importantly International Rice Research Institute (IRRI), Bangladesh Rice Research Institute (BRRI), Bangladesh Agricultural Research Institute (BARI), Bangladesh Livestock Research Institute (BLRT), etc. There is also some institute to control the standards of the products like BSTI.

The Bangladesh Livestock Research Institute so far, achieved a few. Among those, Low cost preservation of green grass, Banana Foliage Processing and Preservation for Feeding Cattle, Use of Coconut Oil Cake, Mustard Oil Cake and Ipil-Ipil in the Diet of Poultry, Calf Rearing (BLRI, n.d.) are remarkable. 
It looks like; the main food (rice) problem is almost solved by BRRI. So far, it delivered sixty one high-yielding modern varieties (MVs) of rice, which can be grown in different season of a six-season country Bangladesh (BRRI, n.d. para. 1). Moreover, they gave a horse with harness. The water management system, increased crop production system, fertilizer and plant management and many more are also the gifts of their research.

Don't you think that we need something more to eat that rice? Going head to head with BRRI or even ahead of it BARI has proven itself since 1960 with the delivery of a tuber crop "Ultimus" (BARI, n.d.). After that, it has never been stopped until today. It presented only in the field of vegetables near about 84 verities. Moreover, in many other fields they worked in similar fashion like - Cereal crops (57), Tuber crops (59), Flower crops (9), Fruit crops (57), and so on.

\subsubsection{Science}

Born in Bangladesh to serve the humankind, Acharya Sir Jagadish Chandra Bose lived as a multidimensional think tank of the Bengali history. His voyages in the branches of polymath, biology, botany, and archaeology and contributions in those fields made him a unique personality. He was a pioneer researcher in radio and microwave optics and made significant contributions in plant science. He established the foundation of experimental science in the Indian subcontinent (Chatterjee, 2002). IEEE honored him as one of the fathers of radio science (Sen, 1997). He also devised Cresco graph, a growth-measuring instrument for plants but never looked for patents.

Azizul Haque, A forgotten name of a pioneer of Henry Classification System of fingerprinting. He worked with Edward Henry to formulate the system, which is being used until today worldwide (Baksh, 1963).

The history of miracle discovery was made by ICDDR'B. It is one of the pioneer institutes for research in public health. Scholars say that the "Oral Saline" was the discovery of the century, which was discovered by the researchers of ICDDR'B (ICDDR'B, 1994). Previously hundreds of people, especially the children, were victimized by Diarrhea and Cholera where this Oral Saline (ORS) alone can manage the patient from dying.

Mohammad Ataul Karim a brand name in the field of applied optics. The vice-precedent of Old Dominion University, Norfolk, Virginia, ranked among the top 50 researchers for his contribution to Applied Optics in its 50 years history (Applied Optics, 2012). He also patented many of his ideas.

In the year 2009, BUET-MIT joint work "Anthropogenic influences on groundwater arsenic concentrations in Bangladesh" by Rebecca B. Neumann et.al, was published in Nature Geosciences (Neumann, 2009). Such a work opened the way of thinking to have safe water for the inhabitants of the world.

Muhammad Anisuzzaman Talukder, Assistant Professor, Department of EEE, BUET has been awarded a United States Patent (Patent No.: US 7,940,818 B2) on May 10, 2011 for his invention of "Passively Modelocked Quantum Cascade Lasers." (Talukder, 2011). Anis's invention opens a path to generate sup-ps pulses in the molecular fingerprint mid-infrared region. These mid-infrared pulses with very high instantaneous power can be used for remote sensing of trace and hazardous gases for environmental safety and medical applications.

Success leads to self-confidence. Maqsudul Alam in the year 2010, decoded Jute's genome sequencing (Naser, 2011) and two years later on September 24, 2012 he again struck by decoding the fungus genome that attacks more than 500 crops (Alam, 2012). Now, it only a matter of time for getting the way out in case of such fungal attack on crops.

\subsubsection{Iraq}

After independence, the kingdom of Iraq established institutes of higher education in different disciplines like law, art, engineering, and medicine. By fifties, University of Bagdad included 12 colleges; different ministries set up their own research facilities. At that time, scholars in different fields, such as, basic science, engineering, medicine etc., started to return from all over the world. Moreover, by the early sixties universities were established in several provinces and graduate programs were started.

In next ten years, more universities with individual colleges and over 80 high technical institutes were founded, accompanied by the Scientific Research Foundation, R \& D Centers, and commissions within ministries. During the late seventies Nuclear Research Center and Nuclear Reactor Activities took place. At that time professional societies and regional associations emerged and many UN projects in science and technology were undertaken (Alnajjar, 2004). Then the Scientific Research Council (SRC) was formed and was strongly supported, well equipped, and notable infrastructure and facilities. SRC also established the power ful National Computer Center for research and training.

During the first Gulf was the SRC was cleared up and the nuclear reactor. The Nuclear Research Center was destroyed and the Military Industrial Commission, R \& D Centers, and other infrastructures were severely damaged in the 
war. Iraq also lost a huge number of scientists, engineers, and researchers then. After year 2000, laws have been changed. Due to success in 1990s, several national programs were recommended in which universities were founded including Al-Nahrain University (former Saddam University), the top among them, regarded as the school of excellence, along with 5 more universities, 54 colleges, and 108 departments. However, after Iraq war almost all of these have collapsed to zero (Alnajjar). At present Iraq, have roughly 32 Public universities and 22 Privet universities, 36 technical colleges.

\subsubsection{Technology}

Recent trend in technology in Iraq seems to be quite positive. Young researchers are working in universities in various fields such as water resources, chemical engineering, applied physics, information technology, and control engineering and so forth (Porter, 2003).

Kareem Hussein Khwedim (Khwedim, 2012), working on water resources analyzed the influence of sewage water on river water, a very contemporary work for urban technology (Khwedim, 2012). Where he found that the contaminants, like $\mathrm{Pb}, \mathrm{Cd} \& \mathrm{Ni}$, in a particular river (Diyala) in Iraq is already above the tolerable range set by WHO. This example can be used to set several researches like this for other part of the country.

Again, in an Iraqi border basin (Badra) Ali et.al. (Ali, 2012) worked on ground water recharging process, which can help them in planning the distribution and consumption of ground water. it can also be used as a foundation work (AlShamaa, 2012).

Al- Naimi working on the livestock health estimated the rate of infection with Paramphistomum in digestive systems of cows (Al-Biaty, 2010). Where, he found that the infection rate is season and age dependent. Another major finding was that the blood vessels are dilated.

Abdullah and Younis (Abdullah, 2011), in the field of computer science developed a new implementation of an established BUDDY system. In this way, they have developed a faster and more organized data management system for the computer operating systems. It also made the system easier to perform its job.

Samir H. Al-Shakir is a researcher in food and agriculture. He was the director of the Agriculture Research Center in the Iraqi Scientific research Council and present Technical Director of Al-Saad Date Production Plant. He has invented and patented several devices, such as, Pollen extracting device Baheth Elmi-Elbo 1984, Ground date palm pollinator AlNahreen 1987, Manual date palm pollinator Hamurabi 1986, Local made filter-aid date juice-extracting Fadylite 1983.

An academician and researcher in optical communications and nano-technology, Professor Samir J. Al-Badar, is British citizen of Iraqi origin. He has 23 publications in world's reputed journals like IEEE.

\subsubsection{Science}

According to the International Society of Iraqi Scientists there are 664 (ISS Iraq, 2010) Iraqi scientists all over the word.

Table 4: Iraqi Scientists all over the world

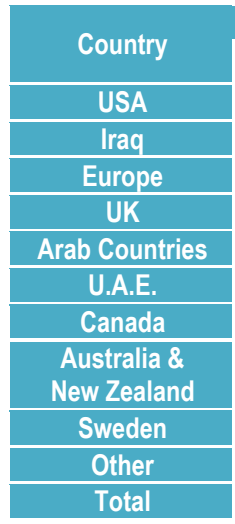

\begin{tabular}{|c|c|}
\hline Art/Social Science & Engin \\
\hline 15 & \\
\hline 17 & \\
\hline 9 & \\
\hline 4 & \\
\hline 7 & \\
\hline 7 & \\
\hline 6 & \\
\hline 2 & \\
\hline 6 & \\
\hline 3 & \\
\hline 76 & \\
\hline
\end{tabular}

\section{Profession}

ISS Iraq (2008)

\begin{tabular}{|c|c|c|c|}
\hline \multicolumn{2}{|c|}{ Profession } & & \\
\hline 28 & Health Professional & Science & \\
\hline 33 & 58 & 30 & 131 \\
\hline 20 & 54 & 49 & 153 \\
\hline 13 & 14 & 14 & 75 \\
\hline 13 & 23 & 22 & 62 \\
\hline 9 & 4 & 22 & 46 \\
\hline 13 & 13 & 15 & 44 \\
\hline 2 & 4 & 11 & 34 \\
\hline 7 & 11 & 10 & 25 \\
\hline 7 & 4 & 7 & 24 \\
\hline 145 & 2 & 5 & 17 \\
\hline
\end{tabular}


As the data show that there are brains of Iraq, scattered all over the world looking for a proper working environment it is for sure that there is a vivid future waiting for them.

The Golden age of Arab science and technology is considered to be from the year 750 to 1258 (Falagas, 2006). Bagdad was one of the centers for creating future back then. Translators were invited there and the scientists were patronized to develop technologies and discover scientific theories. It said that at that time they were ahead of the world for 1000 years in medicine (Syed, 2006.).

Ibn Al-Haitham (Alhazen) (965 - 1040) was a Muslim scientist and polymath born in Basra. He had significant contribution on optics, physics, astronomy, mathematics, ophthalmology, philosophy, visual perception, and on scientific method (Lee, 2001).

A scholar who could challenge the scholar, Muḥammad ibn Jābir al-Ḥarrānī al-Battānī (858 - 929) was an astronomer, astrologer, and mathematician. Several trigonometric relations were his contribution in the field of mathematics, 'Kitāb az-Zij', his unique work, was frequently quoted by many medieval astronomers, like Copernicus (Hartner, 1970). He determined that the solar year is of 365 days, 5 hours, 46 minutes, and 24 seconds (O'Connor, 1999). He corrected Ptolemy's results regarding sun and moon and compiled of his own (Chisholm, 1911). Abu'l-Hasan was a mathematician and wrote a unique piece on positional use of Arabic numerals named "Kitab al-Fusul fi al-Hisab alHindi" in near about 952 (Saidan, 1966).

Ibn Hubal (1122 - 1213) was a physician, and scientist. His unique work was 'Kitab al-Mukhtarat fi al-tibb', 'The Book of Selections in Medicine'. (Hubal, 1165).

Al-Jahiz (781 - 869) was born in Basra; he introduced the concept of food chain and suggested the idea of animal evolution. He wrote on the effects of the environment on the likelihood of an animal to survive, and he first described the struggle for existence. (Al-Khalili, 2008).

"The Philosopher of the Arab", Al-Kindi (801 - 873) was a Muslim Arab philosopher, mathematician, physician, and a musician. He wrote hundreds of articles on metaphysics, ethics, logic, and psychology, to medicine, pharmacology, mathematics, astronomy, astrology, and optics (Corbin, 1993). Further, he moved to more practical topics like, perfumes, swords, jewels, glass, dyes, zoology, tides, mirrors, meteorology, and earthquakes (Adamson, 2006).

An Iraqi-American ecologist, Fakhri A. Bazzaz (1933 - 2008) (Ackerly, 2008) was a renowned professor and author of his field. He remained in ten "Most Cited Scientists in Environment/Ecology, 1992-2002". He was the author of 6 books and over 200 research papers including a scholarly paper on carbon dioxaid (Beth, 2011).

\section{Conclusion}

It is a well-known fact that most of the OIC members are struggling with their development strategies and technologies that they have. One of the major findings of the study is that the science and technology indicators for the OIC member countries display a great disparity within the group members while the OIC countries, individually or as a group, lag far behind the world's developed countries. In view of the assessment of science and technology it can be concluded that the OIC member countries contribute a very small amount to science and technology in modern world considering their high potential, as well as reach cultural heritage and long and vast scholarly tradition. It is also clear that the members have a very little cooperation among themselves rather they are more productive with others. This is may be due to lack of technological resources, facilities, and knowledge that they can have from others but not from themselves.

In case of contribution, the future of science and technology in Bangladesh still needs incubation and in case of Iraq, it needs Intensive Care. Although, various policies has been taken for their development and foreign helps in terms of fund, ideas, technologies, collaboration, supervision is coming, but, the success of the science and Technology Policy and the speed with which the various facets of the policy are implemented depend on an efficient monitoring, review and guidance from an internal governing body.

Conclusively, giving priority to science and technology, encouraging research and development programs, improving institutions, linking postgraduate studies to the comprehensive development plans of the Islamic World, as well as facilitating academic interaction and exchange of knowledge among the academic institutions in the member countries can be the vital policies that can be under taken. 


\section{References}

A. A. Alnajjar, A. M. Nunir, A. L. Pergenzer, and A. C. Littlefield, "International Initiative to Engage Iraq's Science and Technology Community: Report on the Priorities of the Iraqi Science and Technology Community", Sandina National Laboratories, Albuquerque, New Mexico, and Livermore, California, 2004.

A. K. Sen, "Sir J.C. Bose and radio science", Microwave Symposium Digest 2 (8-13), 557-560, 1997.

A. Mir, "Art of the Skyscraper. the Genius of Fazlur Khan", Rizzoli International Publications, 2001.

Abdullah, Nada A.Z., Younis, Manal F. "A New Implementation Echnique for Buddy System" Iraqi Journal of Science 52.3 (2011).

Al-Biaty, Huda S., Kadem, Faozya S., Al- Naimi, Rajiha A.S., and Al -Taae Eman H."Epidemiological and Histopathological Study of Paramphistomum Cervi in Cattle in Babylon Province" Iraqi Journal of Science 51.2 (2010).

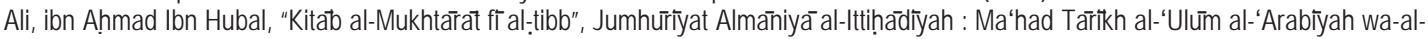
Islāmì̄ah fí Ităr Jāmi'at Frānkfürt, 1996.

Al-Shamaa, Issar M., Ali, Mohammad B. "Estimation of Groundwater Recharge in Badra-Jassan Basin Using Annual Water Surplus Method " Iraqi Journal of Science 53.1 (2012).

Applied Optics. (2012) Retrived November 22, 2012, from http://www.opticsinfobase.org/ao/journal/ao/anniversary/50mostpublished.cfm

B. R. Foster, K. P. Foster, "Civilizations of Ancient Iraq", Princeton University Press, UK, 2009.

Bangladesh Agricultural Research Institute. (n.d.). Achievements. Retrieved November 15, 2012. from http://www.bari.gov.bd/

Bangladesh Bureau of Statistics (2011), Bangladesh Data Sheet. Retrieved November 17, 2012 from http://www.bbs.gov.bd/Home.aspx

Bangladesh Livestock Research Institute. (n.d). Technology Produced. Retrieved Nevember 15, 2012, from http://www.blri.gov.bd/ index.php

Bangladesh Rice Research Institute. (n.d.). Success Stories. Retrieved Nevember 15, 2012, from http://www.brri.gov.bd/

C. K. Maisels, "The Near East: Archaeology in the "Cradle of Civilization", Routledge 1993.

Dabour, N.M. (2000). Eradiation of poverty in the least developed and low-income oic member countries. Journal of Economic Cooperation 21, 1 (2000) 57-96.

Desai, M., Fukuda-Parr, S., Johansson, C., \& Sagasti, F. (2002). Measuring the technology achievement of nations and the capacity to participate in the network age. Journal of Human Development, 3(1), 95-122.

Essential Science Indicators. http://esi.isiknowledge.com/allmenus.cgi?option=1

F. J. Mohan, "Early History of Bengal", Oxford University Press, UK, 2005.

Gupta, Sundeep K., et al. "The chulli water purifier: acceptability and effectiveness of an innovative strategy for household water treatment in Bangladesh." The American journal of tropical medicine and hygiene 78.6 (2008): 979-984.

H. Chisholm, "Albategnius", Encyclopedia Britannica (11th ed.), Cambridge University Press, 1911.

H. Corbin, "History of Islamic philosophy", Kegan Paul International, 1993.

H. J. Nissen, and P. Heine. (2009) "From Mesopotamia to Iraq", The University of Chicago Press.

H. Kulke, D. Rothermund, "A History of India", Croom Helm Australia Pty. Ltd., 1986.

Haylock, S. E. (1979). Khan Bahadur Azizul Haque. Fingerprint World, 5(17), 28-29.

Hussam, Abul, and Abul KM Munir. "A simple and effective arsenic filter based on composite iron matrix: Development and deployment studies for groundwater of Bangladesh." Journal of Environmental Science and Health Part A 42.12 (2007): 1869-1878.

I. B. Syed, "Islamic Medicine: 1000 years ahead of its times." JISHIM 2 (2002): 2-9.

ICDDR, B. (1994). ORS: the history of a miracle discovery. Glimpse, 16, 3-4.

International Society of Iraqi Scientists (ISS Iraq). (2010). ISS Members. Retrieved November 10, 2012 from http://www.issiraq.org/

J. Al-Khalili, "Science: Islam's forgotten geniuses", London: telegraph.co.uk, 2008.

J. J. O'Connor, F. E. Robertson, "Muḥammad ibn Jābir al-Ḥarrānī al-Battān̄̄", MacTutor History of Mathematics archive, University of St Andrews, 1999.

Khwedim, Kareem H. "Iraqi Influence of sewage water on the water quality of Diyala River in Baqubah City." Iraqi Journal of Science 53.1 (2012).

Kirkham, Mary Beth. "Elevated Carbon Dioxide: Impacts on soil and plant water relations" CRC Press, 2011.

Lee, Raymond L., and Alistair B. Fraser. The rainbow bridge: rainbows in art, myth, and science. Penn State University Press, 2001.

M. E. Falagas, A. Z. Effie, and G. Samonis, "Arab science in the golden age (750-1258 CE) and today." The FASEB Journal 20.10 (2006): 1581-1586.

Menyuk, C. R., \& Talukder, M. A. (2011). U.S. Patent No. 7,940,818. Washington, DC: U.S. Patent and Trademark Office.

Naim, T. K. (2008). Mapping scientific research in member states of the Organization of Islamic Conference (OIC). Retrieved December 20, 2012, from http://unesdoc.unesco.org/images/0018/001831/183175e.pdf

Naser, A. The Story of the Golden Fiber of Bangladesh. Marketing ReviewC 107: A Student Journal on Marketing.1.02 (2011).

Neumann, R. B., Ashfaque, K. N., Badruzzaman, A. B. M., Ali, M. A., Shoemaker, J. K., \& Harvey, C. F. (2009). Anthropogenic influences on groundwater arsenic concentrations in Bangladesh. Nature Geoscience, 3(1), 46-52.

Organization of Islamic Conference. (1997). OIC Strategy and Plan of action, SESRTCIC Publications 1997.

Organization of Islamic Cooperation. (n.d.). People's Republic of Bangladesh. Retrived November 17, 2012, from www.icdtoic.org/RS_67/Doc/ln_Fig_BD.pdf.

Organization of Islamic Cooperation. (n.d.). Retrieved November 17, 2012, from http://www.oic-oci.org/ 
P. Adamson, "Al-Kindı- and the reception of Greek philosophy", In Adamson, Peter; Taylor, R.. The Cambridge companion to Arabic philosophy. Cambridge University Press, 2006.

Pickett, Steward TA, and David D. Ackerly. "Fakhri A. Bazzaz 1933-2008."Bulletin of the Ecological Society of America 89.2 (2008): $92-$ 94.

Porter, Alan L. "Iraqi engineering: Where has all the research gone?" Science and Public Policy 30.2 (2003): 97-105.

Ruxin, J. N. (1994). Magic bullet: the history of oral rehydration therapy. Medical History, 38(4), 363.

S. Haj, "The Making of Iraq", State University of New York Press, Albany, 1997.

Saidan, Ahmad S. "The Earliest Extant Arabic Arithmetic Kitāb al-Fusūl fĩ al Hisāb al-Hindī of Abū al-Hasan, Ahmad ibn Ibrāhīm alUqlīdisī." Isis 57.4 (1966): 475-490.

Sena dynasty. (2013). In Encyclopedia Britannica. Retrieve November 25, 2012, from http://www.britannica.com/EBchecked/topic /534287/Sena-dynasty

Teh, B. S., Rahman, A. Y. A., Saito, J. A., Hou, S., \& Alam, M. (2012). Complete genome sequence of the thermophilic bacterium Thermus sp. strain CCB_US3_UF1. Journal of bacteriology, 194(5), 1240.

UN Educational, Scientific and Cultural Organisation, Education under Attack 2010 - Iraq, 10 February 2010.

W. Hartner, "Al-Battānī, Abū 'Abd Allāh Muḥammad Ibn Jābir Ibn Sinān al-Raqqī al-Ḥarrānī al-ābi", Dictionary of Scientific Biography, Charles Scribner's Sons, New York, USA, 1970.

W. R. Polok, "Understanding Iraq", HarperCollins Publishers Inc. USA, 2005.

W. Richard, "Engineering Legends", ASCE Publications, 2005.

Wagner, C. S., Brahmakulam, I., Jackson, B., Wong, A., \& Yoda, T. (2001).Science and Technology Collaboration: Building Capability in Developing Countries (No. RAND/MR-1357.0-WB). Rand Corp Santa Monica Ca. 